\title{
Religious Women in a Chinese City: \\ Ordering the past,
covering the future \\ Ordering the past,
recovering the future
}

Af MARia JaschoK

How do Chinese religious women, specifically Hui Muslims and Catholics experience and negotiate the multiple influences of political ideology, religious norms and commercial desires which complicate public discourses on 'modernity' as a desired outcome of social worth and achievement?

\section{E S S A Y}


ety which since 1949 has been ruled by a Communist Party/state unwaveringly hostile to religious groups. I want to ask what has been the impact on religious minorities, and on religious women in particular, of the state's relentless drive for control of the nation and consolidation of superpower status internationally, (the trope of the 'Pacific Century' is now a staple of many an international meeting (Nonini and Ong, 1997)), of a political history in China which allied modernity for so long to scientific rationality, socialist progress and secular ideology and relegated religion, along with other 'feudal fetters', to the status of subversive Other? Finally, does 'being religious' (as a growing number of Chinese assert they are) make a difference to mainstream society discourses and practices? (As these reflections arise from local ethnographic investigation, any generalisations are by necessity tentative, intended to throw up lines of thought and not generate questionable empirical fixities.)

I shall make use of insights and data from our study ${ }^{2}$ of Islamic female sites, qingzhen nüsi or women's mosques, in particular of our study of the Beida Women's Mosque in Zhengzhou city, Henan province, and from the study of a Catholic site, Zhugu Xiunüyuan or Sister of Providence Convent, in Kaifeng city, also in Henan province. Insights from our on-going research project, based largely on fieldwork and oral history life testimonies, suggest a shared understanding among these religious women of modernity, xiandaibua, as a volatile present-day time, which is felt both to be instilling trepidation and to be inspiring hope, even optimism. Trepidation, because a modernizing Chinese society brings with it loss of previous certainties as to guaranteed livelihood, social and welfare benefits, children's education, adding the unaccustomed vagaries of market society; hope, because legitimate access to comprehensive material and social benefits accruing to Chinese people under a
Maoist/Stalinist state apparatus was predicated on politically correct identities that excluded members of religious groups. Modernity, understood as a loosening of state control and as a growing social space in which diverse, and alternative, identities find expression, is thus bringing also a sense of freedom from the constraints of a developmentalist uni-linearity by which peripheralized members of society were measured by their remoteness from, or closeness to, Communist ideals of progress and modernity (Berktay 1998, Chow 1993).

Suddenly temporalities of another kind can be demonstrated in the cautious reawakening of religious faith, enabling believers to reach back into the long-suppressed past of religious ancestry and to recover hope for a meaningful future through revitalisation of muted traditions. Or, to quote Carol Delaney, what is now possible is a "recuperation of society" (1991) in the open living of faith, enactment of ritual worship, and practice of religious life-style, in which core beliefs in the future as promised eternal life are embedded. Illustrations of these expressions of religiously infused modernity introduce, first, Muslim women's current project of collecting and transcribing sacred chants, jingge, long a tradition of women's mosque, and until recent times forgotten and, secondly, outline Catholic nuns' initiatives to engage more closely, and meaningfully, with their local community. My argument is that we note evidence of ever more diverse participation in public discourses on societal core values, debates in which religious groups are beginning to voice alternative understandings of modernity and development that have resonance for society at large.

\section{RELIGION: DEFINITIONS AND CONTINGENCIES}

The Chinese term for religion, zongjiao, is of Japanese origin and imported into China as recently as the late $19^{\text {th }}$ century (Leung 
1996). The volatility of its history is expressed in the shifting and multiple meanings of zongjiao; it may have the connotation of 'past-ness' expressing the era of China's semi-colonial status, when Western military might and imperial weakness allowed unprecedented missionary inroads into Chinese society (MacInnis 1972, 1989, Uhalley and Wu 2001). Its connotation can also be past-ness understood as 'feudal society', associated with backwardness and ignorance (accusations levelled at members of religious groups, particularly during times of political campaigns). Reference can also be to connotations of 'peripheral' or 'deficient' cultures (where particular ethnic groups are identified in terms of religious faith, such as the Hui/Muslim group, Jaschok and Shui 2000) or, in times of political crisis, religion may be conflated with official treatment of 'non-conformism' or 'splittism' in general (Leung 1996). Given the contingency and arbitrariness of meaning and official treatment, it is not difficult to understand why for many Chinese zongjiao still represents, in certain respects, the very negation of positive collective aspiration for modernity and progress.

\section{CONSTITUTIONAL RIGHTS AND MECHANISMS OF CONTROL}

What are the legal protections given to religious practice? Who is protected, under what circumstances? How are sites of collective worship administered?

The freedom of religious belief is enshrined in Article 36 of the Chinese Constitution (1982) which says:

Citizens of the People's Republic of China enjoy freedom of religious belief. No state organ, public organization or individual may compel citizens to believe in, or not to believe in, any religion; nor may they discriminate against citizens who believe in, or do not believe in, any religion. The state protects normal religious activities. No one may make use of religion to engage in activities that disrupt public order, impair the health of citizens or interfere with the educational system of the state. Religious bodies and religious affairs are not subject to any foreign domination. ${ }^{3}$

Rights enshrined in the Chinese Constitution are more narrow than the Universal Declaration of Human Rights (Arts. 18/1920) and the 1991 UN General Assembly Resolution on the Declaration on the Elimination of All Forms of Intolerance and of Discrimination Based on Religion or Belief (Ibid.). The prerogative of power is manifested in the prerogatives of classification and categorization, and of their maintance through institutionalised mechanisms of control.

Five 'authentic' religions come within the authority of the Administration of the Bureau of Religious Affairs and its monitoring bodies: Islam (overseen by the Chinese Islamic Association), Daoism (Chinese Daoist Association), Protestantism (China Christian Council and Three-Self Patriotic Movement, ${ }^{4}$ Catholicism (Chinese Catholic Bishops Conference and Chinese Catholic Patriotic Association). 'Non-authentic' religions, such as 'sects', 'cults' and 'underground churches' come under the surveillance of the public security apparatus.

Tight registration procedures for approved sites of religious activity were imposed by the Chinese State Council. In 1994, Regulations Regarding the Management of Places of Religious Activity defined rules on proper sites and qualifications of religious professionals in charge of such sites. In the same year, Registration Procedures for Venues for Religious Activities presented comprehensive procedures for successful registration, and in 1996, inspection of religious sites and amendment of rules of registration were laid down in Method for the Annual Inspection of Places of Religious Activities. In all, these mechanisms differed from the Universal 


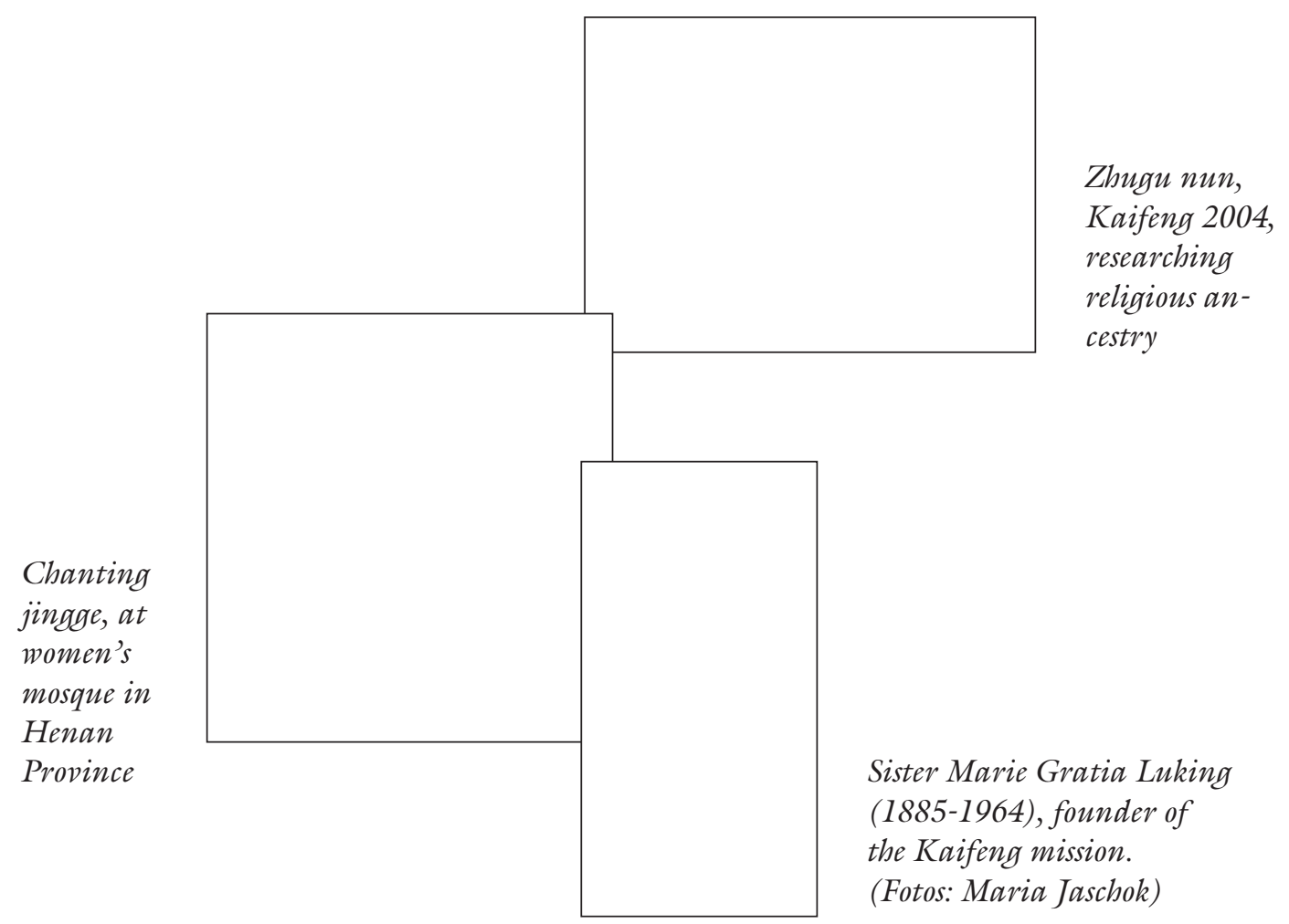


Declaration in making freedom of religion equivalent to freedom of private belief (see Human Rights Watch Asia report of 1997, see note 3 ).

Statistical information regarding the size of Muslim and Catholic population varies, depending on the source consulted. As an approximation, there are between 18 to 25 million Muslims (constituted of ten ethnic groups, Islam thus constituting an ethnic religion in China); the Hui group, which I research, constitutes about half of the total muslim population. There are about 4 to 10 million Catholics. ${ }^{5}$ These very rough estimates are due to the many unregistered religious sites for which there are no membership lists and to the very nebulous criteria for what constitute 'believers' (e.g., not every pastor is ordained, not every Protestant is baptised, and so on).

\section{Place of RELIGION UNDER \\ COMMUNIST RULE SINCE 1949}

Whilst initially the relationship was one of a united front, where religious organizations could identify with principles of justice, liberty, equality, so the Catholic theologian Joseph Tong observes (1999), was shortlived. What ensued was a violent suppression of all forms of religious expression, collective and individual, institutional and private. The Chinese state acquired the character of a 'movement regime' $(\mathrm{H}$. Arendt's term, used by the sociologist Y.H. Chu 1997, 74) with endless streams of decrees, campaigns, movements or selective punitive sanctions inscribing and reinforcing boundary markers of state identity. "The constitution of the people-as-one", Chu noted, "requires the incessant production of enemies" (Ibid.) - among them Christians, Falungong practitioners, house pastors, wиро (witches/charismatic leaders), and the like. Such outright persecution (still under-documented, still muted) gave way to more indirect mechanisms of control only in the late 1970s. That decades of oppression did not erase religiosity, speaks to the enduring faith of those who preserved the knowledge, dared to practise and congregate in secret, and dared to conceal sacred artefacts from all accounts, women were vital carriers of religious knowledge.

\section{RELIGION, COMMUNIST LIBERATION OF WOMEN AND SECULARIZED MODERNITY}

Particular source of tension has been the large, and ever growing, number of female believers, and of female religious leaders. After all, women had been held to constitute the greatest beneficiaries of the Communist revolution, indeed the Party's 'solution' of the women's problem so-called was both the central symbolic and political act of legitimacy of the Communist mandate to govern. Regardless of the mixed record of women's road to nan-nü pingdeng (sexual equality), a record which is coming under ever closer and critical scrutiny of international and Chinese scholars alike, I would argue that women's liberation continues to define for the Communist Party the superiority of its political and legal system in the same way it once defined the struggle for national liberation. Thus Gilmartin, Hershatter, Rofel and White, in an introduction to a seminal anthology, Engendering China, point out that the Communist Party used women's liberation as one of the key categories through which it justified its revolutionary promise (1994, 9). Vivienne Jabri (1996) speaks of the 'myth of origin' which sacralizes oppressive relationships of dependency. "Origin myths are generally thought to form the basis of truth of claims about the authenticity" so says Dru Gladney $(2004,123)$ in a study of Communist state ideology.

What is not sufficiently recognized are the multiple implications for women believers whose faith left them outside, even a negation of, the Communist 'myth of ori- 
gin' (I am not able to go into this in greater detail, but see Jaschok 2003). My argument is that eradication of religion (defined by Mao as one of the four 'feudal fetters') and construction of socialist womanhood, a paradigm awash with socialist rhetoric, were both defining elements of the state's formative phase of consolidation. Attacks on religious believers were, as argued above, connotative of attacks on a backward (feudal) past, on an era of humiliating colonial encroachments and on crippling international dependences. Within a matrix of Communist creation myths, women's liberation narratives, particularly in the most ideology-driven phase of national consolidation after 1949, excluded, and stigmatized those women who continued to identify themselves as religious believers; and these women came to embody everything considered obstructing the path to progress and enlightenment, that is, those attributes on which were predicated state-created utopia of the new era, of new society, of new rights, and of a new people.

Education of the modern socialist citizen was the great revolutionary task of the 1950s and secular, science-informed modernity, at the heart of this educational movement. The history of the All-China Women's Federation (ACWF)'s early campaigns illuminates the sustained attempts to shape Chinese women into socialist, science-minded, sober housewives and labourers with proper political consciousness. Scholarship which covers those years shows how important, and how 'difficult', it was for women to fanshen, to turn from 'superstition' to 'enlightened' socialist subjects (for example, Davin 1979, Wolf 1985).

Even in these more market-orientated times when considerations of national strength, international standing, positive investment climate, enrichment of cultural life, pragmatic use of national and international development resources, and so on, have brought with them greater decentralisation of the state, certain taboos remain, one of these concerns state treatment of organized religion. The Party, as ever, does not countenance rival claims to liberation besides Communist liberation. Whilst women's organizations are allowed to multiply alongside, some even outside, the nationwide branches of the ACWF, assisting the state in needful reforms in the area of women's labour and employment conditions, education, participation in health and welfare campaigns, and the like, exploiting more relaxed State policies to obtain funding also from international funding agencies and NGOs, religious women's organizations face obstacles which, whilst in certain respects most familiar to non-religious women's organizations (lack of funding, uncertain legitimacy of 'popular' organizations, etc), are heightened by religious identity (Hsiung et al 2001). Religious institutions confront persistent difficulties: they operate under surveillance, under highly circumscribed state regulations and rules, always subject to sudden, often arbitrary, fluctuations in official treatment. As pointed out earlier, the historian of Catholicism in China, Beatrice Leung (1996) maintains that religious treatment fluctuates in line with treatment of nonconformists in general (Tiananmen massacre, Falungong repression, etc). So Shui Jingjun writes in a recent article: "Some religious women's organizations would like the support and recognition of institutions such as the ACWF, and a number of religious women intellectuals seek to join the women's movement at large, but they are ignored and their demands neglected" $(2001,115){ }^{6}$

The role of scholarship, as far as religious women's lives are concerned, can be said in the early years of Communist consolidation to have been tightly wedded to the Chinese state project of creating secularized citizens for a socialist utopia. Hannah Papanek (1973) refers to the way that scholarship can be complicit in valorisation of sanctioned values as a 'protective denial' - here 
the denial of rigid exclusion of long female religious traditions of alternative faith and faith-informed practices from master narratives of women's history. Chinese researchers worked largely within orthodox Marxist frameworks in which economics dictated the fate of the nation and formed the base for women's quest for equality. Education, vocational training, employment conditions, all were matters of concern to scholarship that shaped questions over women's lives within the binary of enlightenment, modernity and economic progress defined on the back of feudal and backward, because religion-bound, Others (Susan Harding 1991).

When religion did not wither away during the days of starkest repression and reemerged as a powerful force under more liberal policies in the 1980s, the reason so many women adhered to religious belief, as explained by women's historian Du Fangqin in 1988, must be seen as expression of their vulnerability, even victim status under sometimes brutal conditions of nascent capitalism. Women's inclination for superstition, for comforting religious panacea, underlined it appears, yet again a fundamental inferiority of the female nature. Whilst expressive of societal inequalities, the high percentage of female participation in all religions seems therefore to have perpetuated also an essentialized notion of feminine gullibility and of weak reason (Du 1988). It is of interest to note that recently this same historian published two articles on the implications for gender studies of current research on religion and gender in China. She also indicates a growing awareness on her part of the need to diversify what too long has been the monoparadigmatic interpretation of women's aspirations and ideals (Du 2004). Whilst not representing the whole Chinese women's studies community, nevertheless $\mathrm{Du}$ is a leading force academically and organizationally in China.

\section{MODERNITY AS FREEDOM TO BE RELIGIOUS}

Our study investigates women's own sites of worship and congregation, often with a long and rich history, in diverse religious traditions within the local culture of Kaifeng city and environment and also of Zhengzhou city, which became the provincial capital of Henan province after 1949. We contend that what makes our work so interesting is the fact that at the time of our research, this diverse ethnic and religious local culture is developing complex transnational ties of network and allegiance. These transnational ties are sometimes related to historical origins but some have also more recent beginnings. (Al-Jazeerah footage is as avidly watched in a Chinese village mosque as recent pilgrimages by the pope to Lourdes are the subject of lively conversation among Kaifeng's Catholic nuns.)

Our investigative concerns are the historical and cultural specificities which have shaped the characteristic features of local sites: Foremost, certain religious and cultural gender codes which segregated men and women. We have studied how segregation has in some communities become a desire for autonomy, expressed when women's mosques eagerly registered in 1994 as official religious sites, understanding government regulations as affirmation of women's equal legal standing and equal claims to political representation and $\mathrm{eco}^{-}$ nomic rights (Jaschok and Shui 2000).

Furthermore, identity as Chinese citizens, through recourse to Maoist precepts of gender egalitarianism and rights of equality extended into the religious sphere, are troubling the boundaries of what are politically regimented sites of officially acknowledged worship and entrenched state categories of 'deficient Chinese'. One might argue that religious women use the Communist Party's 'myth of origin' for their own ends. This can be observed when Muslim women in Henan, with the tacit support of local Party officials, take a stand 
against international Islamic orthodoxy which forbids female abong (a title tantamount to imam)-led independent women's mosques (Jaschok and Shui 2000). Indigenization of religion, a consequence in part of the state's prohibition of foreign interference in China's religious organizations, is serving women's interests in unforeseen ways.

It is now possible to observe more proactive religious engagement in society and thus the beginning of a challenge to the developmentalist ideology of the Chinese state. Organized religious women are engaging in social causes, mostly involving marginalized social groups. It will be interesting to observe future developments as religious women (whether through temple, mosque, or convent organization) are beginning to pledge themselves to greater service for community and for the nation with an important, if still un-uttered, caveat: The values underlying this contribution are religiously infused.

\section{Ordering the past}

The history of women's mosques is a long one, its unique manifestation of independent institutions, nüxue or nüsi (women's [Koranic] school or women's mosque) goes back over 300 years, emerging from complex historical and socio-political negotiations over the nature of Muslim identity in Chinese diaspora and over means to keep faith alive and religio-ethnic identity intact. The incorporation of women into educational projects during late Ming and early Qing Islamic renaissance ( $17^{\text {th }}$ century), inspired by Hui Muslim intellectuals and educationalists, was born of the need to bring religious knowledge into families and families into mosques (Allès 2000, Jaschok and Shui 2000). The growth and consolidation of women's own space of worship, education and congregation were only halted with the religious persecutions of the 1950s, and only hesitantly resumed in the course of less repressive government treat- ment of religions during the 1980s. The long period of persecution and silencing of religious expression scars the memories still. Women's mosques have reopened, or, especially in the Muslim communities of central China, have been built anew, most especially since the late $1990 s ; 7^{7}$ but women's connection with the past was too violently ruptured in vicious political campaigns and movements to make remembering anything but a painful groping for a golden past when religion ordered communal meaning.

When we researched into what Shui Jingjun and I knew had been a flourishing feature of female religious culture, women's jingge (religious chants), ${ }^{8}$ we initially encountered silence, feigned ignorance, even outright refusal to acknowledge such a past tradition. It began to change when, on one afternoon, an old lady began to chant.

Everyone was enthralled, particularly as none of the younger women and girls had ever heard jingge. From this unexpected beginning, when the elderly Muslim woman $\mathrm{Li}$ Xiangrong recalled a chant known as kubua (Grieving Song), women together with researchers have begun to collect chants, sometimes mere fragments, which were once the staple of women's mosques. Li Xiangrong, from the famous Wangjia Hutong Women's Mosque in Kaifeng, has stirred rememberings in others of her generation, and the elderly women have begun to teach kuhua to young girls and have started to talk of what life was like for earlier generations of women, particularly the years before the 1949 Communist government, when jingge were at their height of popularity. The chants are now starting to be revived also in neighbouring mosques, with ahong (resident female religious leader) eager to prompt older believers' memory before it is too late. And a bridge is thus spanned across a lost time, with these jingge communicating the suffering, joys, the faith and aspirations of past 
generations of believing women for younger women to hear and to listen to.

But the women who begin to recall old ways of life in which the culture of jingge was embedded are also reaching back into faith which springs from determination to confront vicissitudes. David Coplan remarks that "Oral genres are a people's autobiographical ethnography" (1991, 47) in which identity and self-definition are formulated and maintained. Suddenly the search for ancestry and tradition is spreading among our women informants. And it is now possible for religious leaders such as the influential Islamic woman scholar and ahong, Du Shuzhen from the largest independent women's mosque in Zhengzhou, to commission transcription and compilation of a first ever anthology of women's jingge. Pastness is coming to be filled with sentiments to counter the negative connotation ascribed for so long by society to believing people; and modernity, seemingly paradoxically, is used as a freedom to be religious and to begin to reconnect with the emotions in which their faith had its origins. By doing so, these religious women are also beginning to disengage from the Communist 'myth of origin' of liberation until recently so firmly predicated on the death of alternative visions of liberation.

\section{Recovering the future}

Issues of modernity, as I argued above, invite issues of legitimacy of engagement in societal change. Such an increasingly confident assertion as to the right 'not to be the same' comes from women in my second case study: The Catholic Zhugu (Providence Sisters) Convent in Kaifeng, Henan province. Now exclusively comprised of Chinese nuns, many locally born, their beginnings go back to November 1920 when the American Sisters of Providence, from St Mary's of the Woods, Indiana, arrived that month in Kaifeng, to provide most importantly, and ultimately very successfully, edu- cation for girls, both at primary and high school level. They were active locally until 1950, when all American nuns, and some Chinese nuns and catechists, were forced to leave the country.

Since the 1980s, particularly so since the late 1990s, the Zhugu Sisters have begun to re-engage in educational and charitable causes. Their projects express an emphatic identification with marginalized groups: Whether these are abandoned infants, handicapped children and adults, old people, and, most recently, abused and battered wives.

In many of my interviews, young Zhugu nuns make reference to the early pre-Communist days, when their congregation set up its first Chinese mission, in order to express their understanding of what is 'Chineseness' to a modern and devout Christian, how this might differ from views held by previous generations of Christian Chinese, and how nowadays, in 2004, they negotiate tensions between what is a fervent local nationalism and what are core transnational (Catholic) values. Important contemporary issues of identity and citizenship are related to perceptions of the different positions adopted by early founder nuns. Thus not all American nuns in this early phase are condemned as imperialist; on the other hand, not all are admired. Without detailed knowledge of their founders, Chinese informants associate certain nuns with the status of 'true ancestress' (fieldwork July 2004), and only their photographs are displayed on the reception room table. They refer in equally nuanced ways to earliest Chinese converts/nuns (often their own great-aunt or from a family known to them) as having demonstrated similarly diverse viewpoint and allegiances.

Reconnection to the past has allowed for the more nuanced construction of ancestry, simultaneously, cautious revitalizing of transnational ties and allegiances, not only with mother houses and sister convents elsewhere in Asia but also with internati- 
onal religious funding institutions, invite questions over the ultimate place such sites may occupy in China's rapidly modernizing society.

\section{RELIGIOUS IDENTITIES AND MULTIPLE CONSTRUCTS OF MODERNITY}

The 'expressive culture' (borrowing a term from the anthropologist Rubie S. Watson, 1991) of Henan, China's most populous and centrally located province, is marked by lively ethnic and religious pluralism. We are observing how de-centralization of the state apparatus, economic re-structuring and social change, are facilitating the emergence of a civil space in which alternative religious beliefs find expression. This is taking the form either of an exemplary religious life-style on the part of individual believers or, until recently unthinkable, educational and welfare initiatives organised, financed, and led by religious groups.

I have discussed the attention paid by religious organisations to their ancestry, eit-her through their own historical research or often in conjunction, or in collaboration, with a researcher. Increasingly, such a reinsertion of the religious ancestor into current claims to various rights is done with pride and an assertion to differ. I have also drawn attention to observations as to how believers take advantage of opportunities in a changing society to express an alternative faith and aspiration. With this comes a religious expression of modernity and progress and a challenge to officially sanctioned concepts of what exactly constitutes progress in a society in which religious pluralism has constitutional sanction (if circumscribed and never to be taken for granted). Multiple social, educational and charitable projects are adding specific religious dimensions to notions and practices of development at local level. For the researcher it becomes an imperative to investigate differently positioned subjectivities and how they express relationships between person- hood and community, community and nation, nation and global society.

The tradition of segregated, gendered space for women in China has interesting implications in this modernizing society, not all yet sufficiently understood, but already apparent in religious women's specific contributions to their society, whether on the part of Catholic nuns or of Muslim believers, suffering from the inequalities which arise from the impact of rapid industrialization and unchecked market forces on society's most vulnerable peoples.

In conclusion I would like to quote from a forthcoming article which I co-authored with my collaborator Shui Jingjun. She writes here on the situation of Chinese Muslim women:

Especially as far as women believers are concerned, current Chinese culture is moulded by secular orientation. The religious culture that determines their lives and subjectivities lead to a marginal position of women believers, socially and academically, even to their invisibility in the public (secular) spheres of society ... And yet we have discovered Muslim women to constitute an active religious group, enriching both the history of Chinese Muslims and Chinese history at large. Silence or absence is not equal to non-existence and to the lack of capacity for their own voice. ${ }^{9}$

\section{Noter}

1. October 1st, 2004. Gender and Religion in the 21st Century. University of Copenhagen.

2. These observations come from on-going collaborative ethnographic work of more than ten years' duration. My colleague, the Chinese Hui Muslim sociologist Shui Jingjun from the Henan Academy of Social Sciences in Zhengzhou, and I have focused largely on the history and place of female religious communities in Central China, zhongyuan diqu, comprising the provinces of Henan, Shanxi, Hebei and Shandong.

3. Quoted from Human Rights Watch Asia 
(1997:139) China: state control of religion.

Retrieved from http://www.hrw.org/reports/ $1997 /$ chinal/.

4. 'Three Self' refers to: Self-governing, self-supporting, and self-propagating.

5. Chinese government estimates are of 100 million believers in toto, out of a population of ca. 1.2 billion. But these estimates have remained the same since the 1950s.

6. Shui cites the example of the senior women's mosque administrator Dan Ye's failure to make Zhengzhou city Women's Federation members acknowledge the counselling and welfare work of the Beida Women's Mosque. However, there are also signals which point to a more liberal outlook on the part of individual members of the local Women's Federation.

7. Although no statistics on women's mosques are available, in Muslim communities in provinces in central China the norm is increasingly that where men have their mosque, women too lay claim to one. In some communities, women's mosques outnumber men's mosques (Jaschok and Shui 2000).

8. For history and classification of the genre of jingge, see our chapter in Women in China: The Republican Period in Historical Perspective. Edited by Mechthild Leutner and Nicola Spakowski, LIT, Münster (2005).

9. Extract from our forthcoming article, "Thinking the Unheard, Writing the Unwritten - Collaborating the Feminist Way", to appear in Fashioning Identities and Weaving Networks. Edited by Deborah Bryceson, Judith Okely and Jonathan Webber, Berghalin Books, Oxford.

\section{LITTERATUR}

- Allès, Élisabeth (2000): Musulmans de Chine: Une anthropologie des Hui du Henan, Éditions de L'École des Hautes Études en Sciences Sociales, Paris.

- Berktay, Fatima (1998): Women and religion, Black Rose, London.

. Chow, Rey (1993): Writing Diaspora, Indiana

University Press, Bloomington.

. Chu, Y.H. (1997): 'The counterrevolution - A family of crimes: Chinese Communist revolutionary rhetoric, 1929-89' (69-89) in The web of violence: From interpersonal to global. Edited by J.

Turpin and L.R. Kurtz, University of Illinois Press, Urbana.

. Coplan, David (1991): 'Ethnomusicology and the Meaning of Tradition' in Ethnomusicology and Modern Music History, edited by Stephen Blum, Philip V. Bohlman and Daniel M. Neuman, Urbana, Chicago

- Davin, Delia (1979): Woman-work: women and the Party in revolutionary China, Oxford University Press, Oxford.

- Delaney, Carol (1991): The seed and the soil: gender and cosmology in Turkish village society, University of California Press, Berkeley.

- Du Fangqin (1988): Nüxing guanniande yanbian (Evolution of the concept of femininity), Henan Renmin Chubanshe, Zhengzhou.

. Du Fangqin (2004): “lingleide' jiefang” (The Other Liberation. A Review on The History of Women's Mosques in Chinese Islam) (231-7) in Shehui Xingbie (Gender Studies), 2

- Gilmartin, Christina K., Hershatter, G., Rofel, L. and White, R. (eds.) (1994): Engendering China: Women, culture and the state, MA: Harvard University Press, Cambridge.

- Gladney, Dru (2004): Dislocating China. Reflections on Muslims, Minorities, and Other Subaltern Subjects, Hurst \& Company, London.

- Harding, Susan (1991): "Representing fundamentalism: The problem of the repugnant cultural other" (373-93) in Social research 5

- Hsiung Ping-Chun, Maria Jaschok, Cecilia Milwertz, with Red Chan (eds.) (2001): Chinese Women Organizing: Cadres, feminists, muslims, queers, Berg, Oxford.

- Jabri, Vivienne (1996): Discourses on Violence, Manchester University Press, Manchester.

- Jaschok, Maria (2003): "Violation and Resistance: Women, Religion, and Chinese Statehood" (655-75) in Violence Against Women 9 (6), Sage Publications

- Jaschok, Maria and Shui Jingjun (2000): The History of Women's Mosques in Chinese Islam, Curzon, Richmond. Revised for Chinese language edition:

Zhongguo Qingzhen Nüsishi (2002), Sanlian Chubanshe Harvard-Yenching Library, Beijing. - Jaschok, Maria and Shui Jingjun (2005): "Gender, Religion and Little Traditions: Henanese Women Singing Minguo" in Women in China: The Republican Period in Historical Perspective. Edited by Mechthild Leutner and Nicola Spakowski, LIT Verlag, Münster.

- Jaschok, Maria and Shui Jingjun (2005): “Thinking the Unheard, Writing the Unwritten - Collaborating the Feminist Way" in Fashioning Identities and Weaving Networks. Edited by Deborah Bryceson, Judith Okely, and Jonathan Webber, Berghahn, Oxford.

- Leung, Beatrice (ed.) (1996): Church \& state 
relations in $21^{\text {st }}$ century Asia, University of Hong Kong, Hong Kong.

- MacInnes, Donald E. (1972): Religious policy and practice in Communist China. A documentary history, Hodder and Stoughton, London.

- MacInnes, Donald E. (1989): Religion in China today: Policy and practice, NY: Orbis, Maryknoll.

- Nonini, Donald M. and Aihwa Ong (eds.) (1997): Ungrounded Empires. The Cultural Politics of Modern Chinese Transnationalism, Routledge, New York.

. Papanek, Hannah (1973): "Purdah. Separate worlds and symbolic order" (289-335) in Comparative Study in Society and History, 15

- Shui Jingjun (2001): "The search for sacred women's organizations" (101-19) in Chinese Women Organizing. Cadres, feminists, muslims, queers. Edited by Ping-Chun Hsiung, Maria Jaschok, and Cecilia Milwertz, with Red Chan, Berg, Oxford.
- Tong, Joseph (1999): Challenges and hopes: Stories from the Catholic Church in China, Taiwan: Wisdom Press, Taipei.

. Uhalley, Stephen, Wu Xiaoxin (eds.) (2001): China and Christianity: Burdened Past, Hopeful Future, M.E. Sharpe, New York.

-Watson, Rubie S. (1991): "Wives, concubines and maids. Servitude and kinship in the Hong Kong region, 1900-1940" (231-255) in Marriage and Inequality in Chinese Society. Edited by Rubie $S$. Watson and Patricia Ebrey, University of California Press, Berkeley.

- Wolf, Margery (1985): Revolution postponed: women in contemporary China, CA: Stanford University Press, Stanford.

Dr Maria Jaschok, director of the International Gender Studies Centre, Queen Elizabeth House (Dept of International Development), and senior research scholar at the Institute for Chinese Studies, University of Oxford. 